Pontifícia Universidade $_{\text {do Rio de Janeiro }}$

Denis Franco Silva

DO HUMANO AO PÓS-HUMANO: PESSOA E AUTONOMIA PRIVADA NO CONTEXTO DO APERFEIÇOAMENTO BIÔNICO

Tese de Doutorado

Tese apresentada ao Programa de PósGraduação em Direito do Departamento de Direito da PUC-Rio como requisito parcial para a obtenção do título de Doutor em Direito.

Orientadora: Maria Celina Bodin de Moraes

Rio de Janeiro

Maio de 2009 


\section{DO HUMANO AO PÓS-HUMANO: PESSOA E AUTONOMIA PRIVADA NO CONTEXTO DO APERFEIÇOAMENTO BIÔNICO}

Tese apresentada ao Programa de Pósgraduação em Direito do Departamento de Direito da PUC-Rio como parte dos requisitos parciais para a obtenção do título de Doutor em Direito.

\section{Profa. Maria Celina Bodin de Moraes}

Orientadora

Departamento de Direito - PUC-Rio

Profª. Gisele Guimarães Cittadino

Departamento de Direito- PUC-Rio

Prof ${ }^{a}$. Caitlin Sampaio Mulholland Departamento de Direito- PUC-Rio

Prof. Carlos Edison do Rêgo Monteiro Filho

Departamento de Direito - UERJ

Prof. Eduardo Ribeiro Moreira Departamento de Direito- UFRJ

Prof. Nizar Messari Vice-Decano de Pós-Graduação do Centro de Ciências Sociais - PUC-Rio

Rio de Janeiro, 12 de maio de 2009. 
Todos os direitos reservados. É proibida a reprodução total ou parcial do trabalho sem autorização da universidade, da autora e do orientador.

\section{Denis Franco Silva}

Possui graduação em Direito pela Universidade Federal de Juiz de Fora (2000), mestrado em Direito pela Universidade Federal de Minas Gerais (2004). Atualmente é professor adjunto da Universidade Federal de Juiz de Fora. Tem experiência na área de Direito, com ênfase em Direito Civil, Direito Comercial, Teoria Geral do Direito, Filosofia do Direito e Bioética.

Ficha Catalográfica

Silva, Denis Franco

Do humano ao pós-humano: pessoa e autonomia privada no contexto do aperfeiçoamento biônico / Denis Franco Silva ; orientadora: Maria Celina Bodin de Moraes. - 2009.

123 f. ; $30 \mathrm{~cm}$

Tese (Doutorado em Direito)-Pontifícia Universidade Católica do Rio de Janeiro, Rio de Janeiro, 2009.

Inclui bibliografia

1. Direito - Teses. 2. Pós-humanismo. 3. Corpo. 4. Pessoa. 5. Autonomia. 6. Biônica. I. Moraes, Maria Celina Bodin de. II. Pontifícia Universidade Católica do Rio de Janeiro. Departamento de Direito. III. Título. 


\section{RESUMO}

SILVA, Denis Franco; Moraes, Maria Celina Bodin de. Do humano ao pós-humano: pessoa e autonomia privada no contexto do aperfeiçoamento biônico. Rio de Janeiro. 2009. 123p. Tese de Doutorado. Departamento de Direito. Pontifícia Universidade Católica do Rio de Janeiro.

O trabalho procura investigar os limites da autonomia privada na estrutura de um direito subjetivo ao próprio corpo e a possibilidade de submeterse a pessoa a um processo de auto-aperfeiçoamento biônico. Parte-se da identificação de uma base teórica adequada à integração do elemento corporal a um conceito normativo de pessoa. A partir daí, identifica-se a proteção à personalidade com a proteção da identidade pessoal, propondo-se um modelo de direito subjetivo ao corpo em analogia com o conceito de soberania. Definida a autonomia em uma perspectiva de cooriginariedade entre autonomia pública e privada, os critérios utilizados para justificar intervenções em seu exercício baseiam-se em duas premissas: i) o ato interventivo restringe-se a situações na quais existem efeitos colaterais do exercício do agir autônomo em outras esferas de soberania ou no espaço relacional e ii) somente se pode intervir através de normas às quais todos poderiam consentir como participantes de um discurso racional. Concluindo-se que não há identidade entre pessoa e a base biológica humana, mesmo que se modifique radicalmente o sujeito, continuará a ser pessoa. Encontrando-se a fusão homem-máquina inserida em sua esfera de soberania, se admite intervenções quando se invade a esfera de soberania de outro agente. Quanto a intervenções fundadas em reflexos sobre o espaço relacional, estas devem se limitar à regulamentação da utilização dos upgrades, buscando-se preservar a autonomia pessoal do agente, bem como a autonomia e outros interesses daqueles não modificados.

\section{Palavras-chave}

Pós-humanismo; Corpo; Pessoa; Autonomia; Biônica. 


\section{ABSTRACT}

SILVA, Denis Franco; Moraes, Maria Celina Bodin de (Advisor) From Human To Posthuman: Person And Private Autonomy In The Context Of Bionic Body Modifications. Rio de Janeiro. 2009. 123p. PhD. Thesis. Departamento de Direito. Pontifícia Universidade Católica do Rio de Janeiro.

The aim of this study is to propose an investigation related to the limits of private autonomy, taking into account the structure of the right to someone's free use of his(her) own body as well as the possibility of the usage of bionics selfdevelopment of human body. Once a theoretical reference is identified in order to relate the corporal element to a normative concept of person, the protection of one's personality may be directly referred to the protection of a personal identity. In this vein, a subjective right to one's own body is proposed in analogy to the concept of sovereignty. Defining the autonomy in accordance with the dialectical relation between private and public autonomy, the criteria used to justify the intervention in the exercise of autonomy are based on two premises: i) the act of intervention is restricted to situations in which there are collateral effects of the specific autonomous act in other spheres of sovereignty and in the relational space and ii) it is possible to intervene in any sphere of free will if and only if the norms proposing the intervention can be the product of consensus of all participants in a rational discourse. Asserting that there is no identity at all between a person and the biological status of being human, it is logical to conclude that, even if the self is completely change by any kind of bionics technology, he or she will still remain a person. Even though the fusion of man and machine is within his (her) sphere of sovereignty, normative intervention is permitted in case of invading the sphere of sovereignty of another agent. In addition, so as to protect the relational space among different selves, normative intervention ought to be limited to the regulation of the use of upgrades. The purpose here is to preserve the personal autonomy of the agent as well as the autonomy and other interests from those not modified by the upgrades.

\section{Keyword}

Posthumanism; Body; Person; Autonomy; Bionics. 


\section{SUMÁRIO}

$\begin{array}{ll}1 \text { INTRODUÇÃO } & 08\end{array}$

2 CORPO, PESSOA E DIREITOS DE PERSONALIDADE 12

2.1 As relações entre corpo e mente: o corpo humano e a pessoa 12

2.2 Um conceito normativo de pessoa 24

2.3 Pessoa e direitos de personalidade 35

2.4 Ter um corpo ou ser um corpo? Como se subjetiva o direito ao próprio corpo $\quad$. 42

3 AUTONOMIA PRIVADA: TRANSIÇÕES E INTERFERÊNCIAS 49

3.1 Da moralidade ao Direito: as bases do conceito moderno de autonomia privada 49

3.2 Autonomia privada: sobreposição ou submissão à autonomia política? 53

3.3 A idéia de cooriginariedade entre autonomia pública e autonomia privada $\quad 55$

3.4 A autonomia como valor fundante $\quad 59$

3.5 Intervenções na autonomia a partir de uma perspectiva
cooriginária

3.6 Justificação e adequação: um esclarecimento quanto ao nível argumentativo/discursivo da investigação das limitações ao exercício da autonomia $\quad 66$

4 AUTONOMIA PRIVADA E BIÔNICA: A METÁFORA DO
HOMEM-MÁQUINA EM SUAS ÚLTIMAS CONSEQÜÊNCIAS?

4.1 O corpo obsoleto $\quad 70$

4.2 De Prometeu a Fausto: biotecnologia e transcendência $\begin{array}{ll}\text { do humano } & 76\end{array}$

4.3 Fusões homem-máquina e o status de pessoa $\quad 80$

4.4 Os limites do aperfeiçoamento funcional 90

5 CONSIDERAÇÕES FINAIS 107

6 REFERÊNCIAS BIBLIOGRÁFICAS 112 


\section{Lista de Figuras}

Figura 1 - Sétima gravura dos músculos, Andreas Vesalius.

De humani corporis fabrica, 1543, Veneza

Figura 2 - A lição de anatomia do Professor Tulp. Rembrandt.. 1632, Mauritshuis

Figura 3 - Representação gráfica das relações entre autonomia pública e privada

Figura 4 - A terceira mão.

Figura 5 - Exoesqueleto sendo utilizado em performance.

Figura 6 -Oscar Pistorius em competição com suas próteses

Cheetah Flex-Foot. Foto de Gregorio Borgia

Figura 7 - $\mathrm{O}$ ator Peter Weller em cena de RoboCop. Orion Pictures,

Figura 8 - Mão biônica I-Limb com life-like covering

Figura 9 - Protótipo de olho biônico. Um óculos equipado com uma câmera envia sinais para um implante na retina que os descarrega ; diretamente no nervo ótico ou, em caso de lesão deste, diretamente no córtex visual através de eletrodos

Figura 10 - Mão biônica da Touch Bionics. Com motores individuais para cada um dos dedos e totalmente articulada, executa movimentos com precisão e força similares a uma mão natural.

Figura 11 - Esfíncter biônico. Projetado para combater incontinência fecal severa, ele estimula o esfíncter normal do paciente para lhe conferir controle sobre a evacuação através de um sistema pressurizado 